\title{
Dangerous Goods Transportations in Inland Waterways A Case Study for Indonesia Waterways
}

\author{
Fariz Maulana Noor ${ }^{1, a, *}$ and Taufik Fajar Nugroho ${ }^{2, b}$ \\ ${ }^{1}$ Laboratory for Hydrodynamycs Technology, Agency for The Assessment and Application of \\ Technology, Surabaya, Indonesia \\ ${ }^{2}$ Marine Engineering Department, Sepuluh Nopember Institute of Technology, Surabaya, Indonesia \\ a.fariz.maulana@bppt.go.id,b.tfnugroho@gmail.com \\ *corresponding author
}

Keywords: RoPax ferry, Inland waterways, IMDG, dangerous goods, Crossing Port

Abstract: In archipelagic countries, like Indonesia, RoPax ferry service will be a catalyst for the growth of the area because low transportation costs will increase the competitiveness of the area so that exports and imports from the area will increase. However, accidents involving domestic RoPax ferries in Indonesia have resulted in catastrophic consequences of loss of life and damage to property. One of the causes of accidents in RoPax ferries that has resulted in catastrophic consequence is the mishandling of dangerous goods. By its nature, transportation of dangerous goods by domestic ferry can be considered as one of the most dangerous maritime transport forms because a single accident involving a domestic RoPax ferry that carries dangerous goods and passengers at the same time, can cause both environmental catastrophe and severe human casualties. This research, describes the handling process of vehicles with dangerous goods in Merak Port, Ketapang Port and Bajoe' Port in Indonesia. Through this research, it was found that Ketapang Port and Merak Port have procedures for handling dangerous goods developed based on technical guidance from PT. ASDP Indonesia Ferry. However, many violations are committed by officers in the field during the implementation of these procedures. In addition, the limited facilities owned by the ferry port and RoPax ferry, have made it difficult to implement the existing procedures, especially to fulfil the segregation procedure for vehicles carrying dangerous goods.

\section{Introduction}

For archipelagic developing countries, especially Indonesia, “domestic ferries play a significant role in" the regular inland waterway transportation of numerous passengers and cargoes. "The common ferry type used in developing-archipelagic countries is the RoPax ferry. RoPax ferries typically carry passengers, vehicles and cargo at the same time. There are so many types of cargo carried by land transportation vehicles through domestic ferries and one type of cargo is dangerous goods. Dangerous goods are commonly known as hazardous materials, and include flammable, explosive, radioactive, oxidizing, corrosive, toxic, pathogenic or allergenic substances. 
The transport of dangerous goods between islands in Indonesia is done by domestic RoPax ferries which, simultaneously, carry passengers between islands. By its nature, transport of dangerous goods by domestic ferry can be considered as one of the most dangerous maritime transport activity because a single accident involving a domestic RoPax ferry that carries dangerous goods and passengers at the same time, could cause both environmental catastrophe and severe human casualties. More than 10 thousand substances are classed as dangerous goods that can cause the death of people, environmental disaster or destruction of properties if mishandled (ILO, 2004).

Handling, stacking, stowage, loading and unloading of dangerous goods to and from such ships should be done by workers who have the competency and are equipped with safety equipment. Furthermore, the shipping company transporting dangerous goods via domestic ferry must inform the port officer and harbour master before loading special goods, vehicles and dangerous goods or entering the port limit.

The existence of hazardous cargo in vehicles boarding the ferry for transhipment causes difficulties in surveillance and precise inspection of hazardous cargo. Furthermore, cargo owners' awareness of the damage that dangerous cargo can cause is still very low. They often do not comply with the regulations for transporting dangerous goods. For example, the owners of dangerous goods do not properly classify their cargo as dangerous cargo and do not clearly identify it as such by displaying the appropriate dangerous goods safety mark, label or placard.

To ensure the safety and security of domestic ferry transport services, port authorities have developed handling procedures for dangerous goods carried by RoPax services. However, the procedure developed by the port authority has not been supported by government regulation, creating some issues in its implementation.

\section{Dangerous Goods Handling and Possibility of Hazard}

\subsection{Definition of Dangerous Goods}

In the maritime literature and legislation, expressions such as "dangerous cargoes and goods" and "hazardous material" can be seen. However, the diversity of terminology raises the question "What are the differences between these words and terms?" According to Smith (2014), a senior instructor and consultant on dangerous goods and Hazmat, "dangerous goods" and "hazardous material" are fairly interchangeable. To better distinguish between them in the transport chain, dangerous goods should be called "Dangerous Cargoes.

In SOLAS Chapter VII regulation 1 dangerous goods defines as the substances, materials and articles covered by IMDG Code and MARPOL Annex III Chapter 1 (General) regulation 1 defined harmful substances as those substances which are identified as marine pollutants in the IMDG Code or which meet the criteria in the appendix of Annex III MARPOL.

However, to simplify the definition of Dangerous Cargoes, we can define dangerous cargoes as substances which, due to their properties and or concentrations and/or quantities, may, either directly or indirectly, pollute and/or damage the environment, and/or adversely affect the health and survival of humans and other living organisms and cause damage to property.

\subsection{The Classification of Dangerous Goods}

At present, millions of harmful chemicals are listed on the world market and more than one hundred thousand of them are trade in the world market (Brunings, 2017). More than 10 thousand new chemicals are developed every year and about 2000 of them enter the industrial sector worldwide. 
The transport of dangerous goods by sea faces a significant problem as the quantity of dangerous goods shipped by sea has increased significantly, and the amount of cargo carried by ship exceeds land transport. For example, chemical tankers can carry more than 2000 times the amount of cargo that land trucks carry.

It is important to classify dangerous goods into different classes based on the specific chemical characteristics producing the risk. On the basis of substance characteristics, United Nations (UN) experts on dangerous goods transport published the "Minimum Requirements for the Transportation of Dangerous Goods" in 1956. This book describes chemicals classed as dangerous goods and divides them into nine groups according to their characteristics. These groups are the following:
a. Explosives
b. Gases
c. Flammable liquids
d. Flammable solids
e. Oxidizing substances
f. Poisonous substances
g. Radioactive materials
h. Corrosives
i. Miscellaneous dangerous goods

However, to simplify the grouping of dangerous goods, the types of "dangerous goods based on their origin and characteristics can also be classified as follows:

a. Oil by-products - Fire and explosion are their main risk (Benzenes, liquefied petroleum gas and other fuel products)

b. Chemical products (industrial, pharmaceutical and agricultural) - Manufactured and loaded either as final product for consumption or as by-products for industrial use. The latter are the majority of the dangerous goods transported and could cause great damage to people, transport units and the marine environment.

c. Minerals - Such as coal, sulfur, mineral concentrates and other metals or asbestos which can cause many types of illnesses, toxification or fire.

d. Products of animal or vegetable origin - Such as fishmeal, pressed cakes of oleaginous seeds and cotton, which can cause spontaneous combustion, fire or explosion.

e. Radioactive materials - Used in a variety of industrial and medical processes, as well as for military applications. These could cause cancer and other critical illnesses with prolonged exposure."

\subsection{Possible Danger from Mishandling of Dangerous Cargoes}

The mishandling of dangerous cargoes can cause many types of accidents such as fire, explosion, contamination and radiation. Furthermore, mishandling of dangerous cargoes can kill humans and other living organisms, destroy the environment by water pollution, destroy property and affect the economy.

\section{Research Methodology}

Chapter three will describe the work process that will be implemented to support this research. The flow chart of this work process is illustrated in Fig. 1. In the flow chart, the implementation of the study is divided into 4 (four) stages of work, namely: (i) preparation, (ii) Data Collection, (iii) analysis and (iv) recommendations and suggestions. 


\subsection{Secondary data collection}

The study process will begin with the collection of secondary data covering the inventory of previous studies, references, policies and plans of central / local governments and other relevant secondary data. Secondary data collection will be conducted at central government agencies through an institutional survey.

In this phase, some of the data has been collected from previous studies. Based on the secondary data, a review of the condition of transport and management of dangerous goods will be conducted.

Secondary data will be gathered from documents of port operation and ferry operation. Data will be collected from PT. ASDP Indonesia Ferry and Ministry of Transportation.

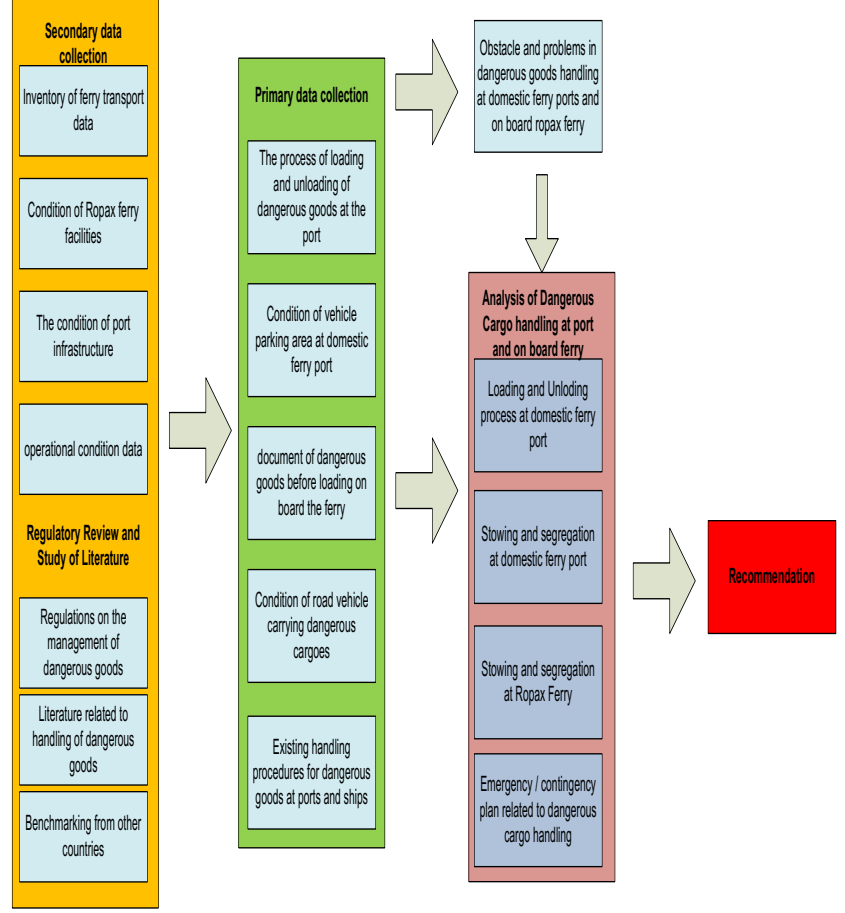

Figure 1: Research Flow Chart

\subsection{Primary data collection}

Primary data will be obtained from field data collection. The main purpose of field data collection is to collect the data required for the analysis of the transport and handling of dangerous goods at ferry ports and on board RoPax ferries.

\subsection{Inventory of obstacles and issues of dangerous goods handling}

After the data needed for the analysis process has been successfully collected, the next process is to compile, process and analyse the data. To support data compilation, processing and analysis, data processing software (MS Excel) is used. An inventory of the obstacles and problems in the transport and handling of dangerous goods is required to improve the current system.

The inputs used in the inventory process include:

Portrait of operational conditions in the field of the transport and handling of dangerous goods;

a. The process of monitoring of dangerous goods;

b. Documents used in the process of transporting dangerous goods;

c. Local government policy on handling of dangerous goods; 
d. Interviews with related parties in the field, such as: driver, shipping company and field officers

\subsection{Analysis of dangerous cargo handling in port and onboard ferry}

During this stage, an analysis will be conducted of the secondary and primary data collection results from the previous stage. Furthermore, this analysis identifies the obstacles and problems that occur when handling dangerous goods, mainly related to the transport and handling of dangerous goods in the Port and on board vessels.

\subsection{Recommendation}

The study results will be used as the basis for regulation and framework development of dangerous goods handling by domestic ferry transport. The regulation is expected to be flexible so that it can be applied in all domestic ferry ports in Indonesia.

\section{Dangerous Goods Transportation in Indonesian Domestic RoPax Operation}

Indonesia has more than 30 domestic crossing routes. However, this chapter will explain the existing condition of three main domestic crossing routes: Merak - Bakaheuni, Ketapang - Gilimanuk and Bajoe' - Kolaka.

\subsection{Merak - Bakaheuni Crossing Route}

The track distance for the Merak - Bakauheni crossing route is 15 miles. The operation frequency (number of trips) within 1 (one) year for the Merak - Bakauheni crossing route in 2011 was 29,431 trips (one way) for RoPax vessels and 444 trips (one way) for fast vessels. The vessels operated on Merak - Bakuheni crossing track in 2009 were 33 RoPax Ships and 3 Fast Ships.

The arrangement of vehicles carrying dangerous goods through Merak Port based on field survey results is as follows:

a. Vehicle types that often use ferry facilities at Merak Port are vehicles carrying fuel, asphalt, used oil, gas, liquid chemicals and crude oil.

b. Merak Port has provided a special parking area for vehicles carrying dangerous goods. However, in some situations and conditions, utilization of such special areas for such vehicles is not evident, especially if the port is full of queues of vehicles caused by delays in ship schedules. Fig. 2 shows that vehicles carrying dangerous goods did not use the special parking area and are parked in the same area with other trucks or vehicles.

c. The port authority has a standard procedure for vehicles carrying dangerous goods cargo. However, it is still lacking in the application of this procedure in the field, especially when the harbour is full of queues of vehicles. This needs to be evaluated. 


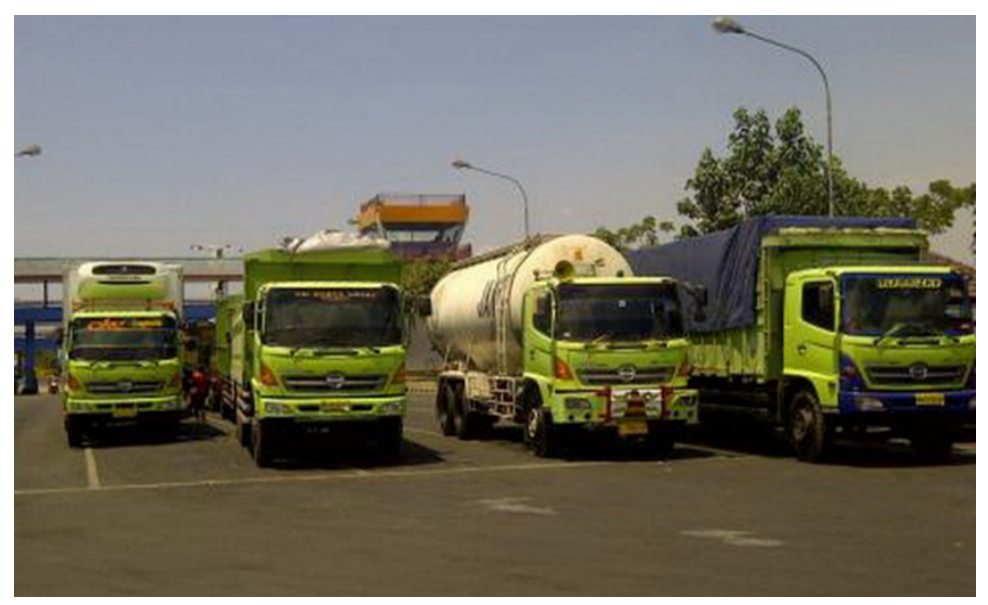

Figure 2: Road vehicle carrying dangerous goods in Merak Port parking area

\subsection{Ketapang - Gillimanuk Crossing Route}

PT. ASDP Indonesia Ferry (Persero) Ketapang is a branch office of PT. ASDP located in Ketapang, Banyuwangi, East Java Province. The office is a branch office of PT. ASDP with Classification A. Classification A means that Ketapang Port has a passenger volume more than 2000, jetty capacities 1000 GRT and operates 24 hours nonstop. This port serves only one route, Ketapang - Gilimanuk path with Gilimanuk Port is located in Bali Province. The Ketapang - Gilimanuk crossing route is an inter-province commercial crossing connecting East Java Province on Java Island with Bali Province on the Island of Bali.

The route distance for the Ketapang to Gilimanuk crossing is six nautical miles. Operation frequency (number of trips) in one year for Ketapang - Gilimanuk in 2011 was 141.158 trips. The number of Ferries on the Ketapang - Gilimanuk route is 24 vessels, divided into 14 RoPax vessels using the Moveable Bridge and 10 ships using the Beaching Dock.

The process flow of activities in Ketapang Port can be seen from the Layout of Ketapang Ferry Port as shown in Fig. 3.

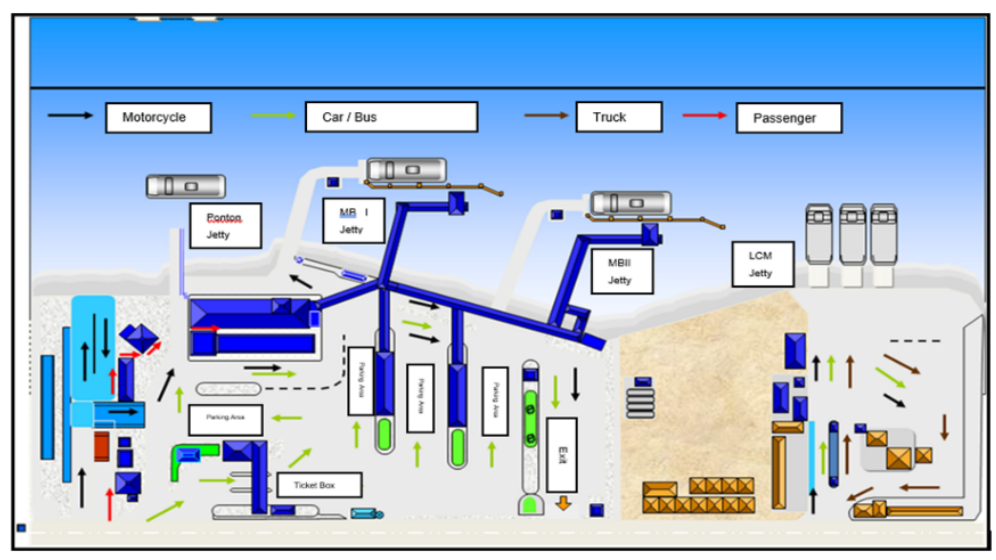

Figure 3: Ketapang port layout

Passengers without vehicles enter from the left side of the image to the waiting room (or just pass through) via a special pedestrian path. They buy tickets at the counter before entering the waiting room. From the waiting room, passengers go to the ferry through the gangway on the Jetty where the ferry is waiting to travel, and finally arrive at the port of destination. Vehicles access Ketapang Port via the vehicle line and pay for tickets via the counter located at the gate to the vehicle path. From 
the ticket counter, vehicles are directed by the officer to park according to the type of vehicle and cargo. The parking also use as a place for the port officers to manage the vehicle before on board the ferry. For vehicles with a payload over two tonnes, the officer will direct the vehicle to a special Jetty for Landing Craft Mechanized ships, which is used solely for large vehicles with large tonnage.

The arrangement of vehicles carrying dangerous goods through Ketapang Port based on field survey results is as follows:

1. Vehicles carrying dangerous cargoes that frequently use the ferry facilities in Ketapang port are vehicles (trucks) carrying fuel, liquid chemicals and gas.

2. The port authorities provide a special parking lot for vehicles with dangerous goods cargoes; however, based on interviews conducted with drivers, vehicles with dangerous goods cargo often park alongside other vehicles, as seen in Fig. 4.

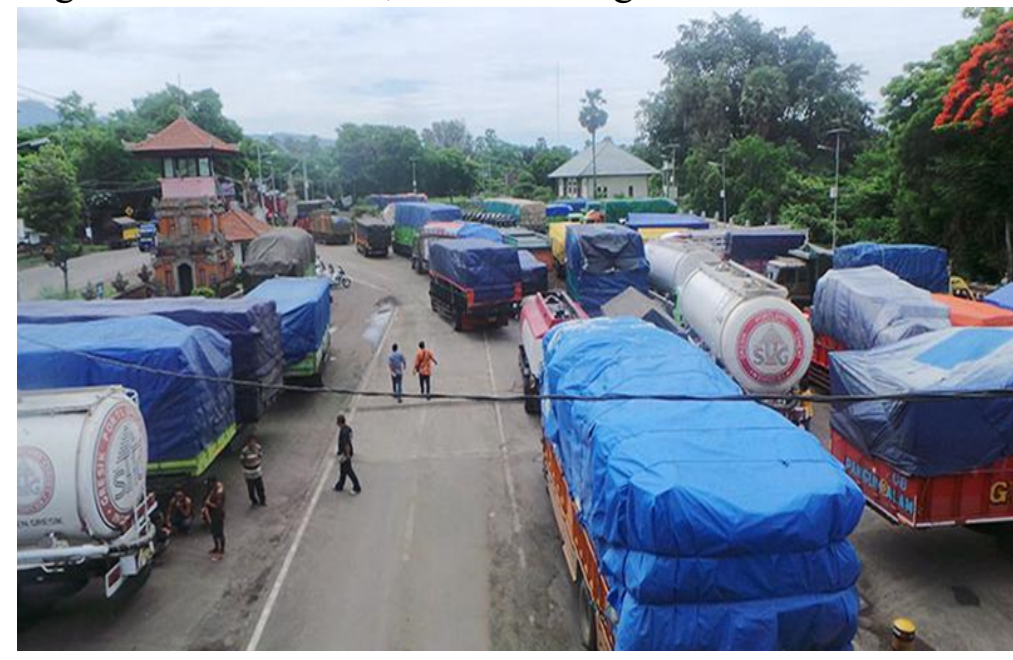

Figure 4: Vehicle parking area in Port of Ketapang

3. For port facilities associated with the prevention of dangerous goods accidents are still very limited and inadequate.

4. The Ketapang port authority has set up a Standard Operation Procedure (SOP) on the handling of dangerous cargoes, especially those carried by vehicles.

\subsection{Bajoe' - Kolaka Crossing Routes}

Bajoe' - Kolaka crossing route has a distance of 86 nautical miles. The route connects Bajoe' in South Sulawesi Province and Kolaka in Southeast Sulawesi Province. The Bajoe' - Kolaka crossing line is the economic pulse that connects South Sulawesi Province with Southeast Sulawesi through Bone Bay.

Bajoe'- Kolaka crossing line is the main transportation route for natural product shipments from Southeast Sulawesi, especially marine products (fish and seaweed), while from South Sulawesi, this crossing is widely used to send foodstuff and household appliances such as refrigerators, televisions and other electronic equipment.

Travel time to complete the Bajoe' - Kolaka crossing is more than 10 hours. The length of the journey is due to the necessity for the ship to follow a safe path through waves and wind. Weather conditions at the Bajoe'-Kolaka crossing line are currently difficult to predict. Current and weather conditions are strongly affected by global weather conditions and may change at any time. Weather information can be obtained from Indonesia Meteorological, Climatological, and Geophysical Agency (BMKG). Bad weather often occurs on the Bajoe' crossing route to Kolaka, causing frequent delays of vessels operating on the line. Delays in the schedule cause the accumulation of passengers 
and vehicles in ports and the availability of parking spaces is inadequate. In 2015, 9 RoPax ships were operating on the Bajoe' - Kolaka crossing.

The arrangement of vehicles carrying dangerous goods through Bajoe' Port based on field survey results is as follows:

1. Vehicles carrying dangerous cargoes that frequently use the ferry facilities at Bajoe' Port are vehicles (trucks) carrying fuel and gas by PT. PERTAMINA (Persero)

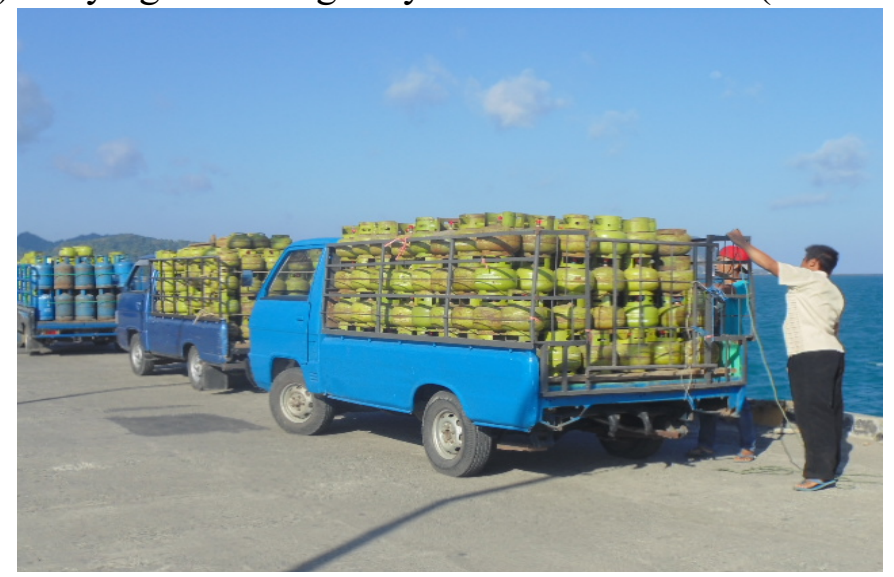

Figure 5: Vehicle carrying LPG parking in Bajoe' Port

2. Port facilities associated with the prevention of dangerous goods accidents are still very limited and inadequate (only fire extinguisher)

3. The port authority has no contingency plan, especially in the case of ferry schedule delays due to bad weather. The port authority needs to develop a contingency plan, especially regarding emergencies that arise dangerous goods in the limited parking area at the port when ferry schedule delays.

\subsection{Indonesia Regulation of dangerous goods handling in port and onboard ferry}

Act Number 17, 2008, is a substitute for Act Number 21, 1992, on Shipping. In the case of dangerous goods transport, Act No. 17 of 2008 states that the transport of special goods and dangerous goods shall be carried out in accordance with the provisions of laws and regulations.

Article 45 stipulates that the owner, operator, and / or agent of a sea transport company carrying dangerous goods and special goods shall be required to give notice to port authorities (Syahbandar) before the dangerous goods arrive at the port.

Port Business Entities and Port Operating Units are required to provide stowage or stockpiling for dangerous goods and special goods to ensure the safe and smooth flow of goods in port traffic, and is responsible for the preparation of systems and procedures for handling dangerous goods and special goods at ports.

Furthermore, this law stipulates that further provisions on the procedure of transporting special and hazardous goods shall be regulated by a Government Regulation

Government Regulation No. 20 of 2010, concerning transportation on water, is an elaboration of Act No. 17 of 2008. This government regulation deals with sea transport, river and lake transportation and ferry transportation; service activities related to transport on water; licensing of various businesses related to water transport; obligations and responsibilities of the carrier; transport of special and dangerous goods; empowerment of the national water transport industry; and administrative sanctions.

Matters relating to the carriage of special and hazardous goods declared in this government regulation, which are not stated in Law No. 22 of 2008 concerning voyages, are as follow: 
A. In the case of regulations concerning the provision of special goods and hazardous goods, this government regulation requires special venues and specialized ships for the transport and unloading of special and dangerous goods.

B. The management of dangerous goods must also be done by a competent workforce, equipped with safety facilities. Furthermore, this government regulation states that further provisions concerning port transportation and handling of special and dangerous goods shall be governed by a Ministerial Regulation.

\section{Analysis of Dangerous Goods Handling in Domestic RoPax Ferry Operation}

Inter-island ferry transportation in Indonesia is conducted by several operators, and one of the largest operators is PT. ASDP Indonesia Ferry. As one of the ferry crossing operators, PT. ASDP has implemented safety standards on all ship operations. PT. ASDP also serves as an operator in several ferry ports, so it also manages the handling of dangerous goods cargo in the port, before entering the ship.

\subsection{Analysis of dangerous goods handling at domestic RoPax ferry port}

PT. ASDP has prepared an operating standard for handling dangerous goods cargo transported by their ferries. Standard operation for handling dangerous goods at PT. ASDP is described in document number OPS-109 issued by PT. ASDP on November 1, 2005. However, there are some ports and ferries that are not operated by PT. ASDP but operated by the local government. This causes inequality in the service standards of vehicles with dangerous goods cargo. Additionally, the operators in the field have failed to fully implement the rules and procedures.

Dangerous goods transport between islands in Indonesia is dominated by transport of fuels and LPG cylinders. More than 80 percent of dangerous goods transport involves the transport of fuel oil and LPG cylinders using RoPax Ferry crossing services to distribute the cargo throughout Indonesia.

Currently, there are 35 ferry ports in Indonesia. However, all 35 ports still have low service standards and poor facilities. Based on surveys of three ferry ports (Merak Port, Ketepang Port and Bajoe" Port), it can be seen that in all three ports, service performance and standards for dangerous goods handling are still below the recommended levels as indicated IMO through MSC1. Circ. 1216, "Revised Recommendation on The Safe Transport of Dangerous Cargoes and Related Activities in Port Areas". One of the requirements listed in MSC1. Circ. 1216 paragraph 3.4 states that each port must have specific consideration for warehouses and terminal areas for dangerous cargo. However, none of the ferry ports in Indonesia have warehouses and only a few ferry ports have special parking areas for vehicles carrying dangerous goods cargo.

\subsection{Analysis of stowing and segregation on board RoPax ferry}

Based on data from the Directorate General of Land Transportation (DGLT), in 2014, the number of RoPax ferry boats operating in Indonesia about 258 units, with ship ages varying from five to 50 years. More than $50 \%$ of the domestic RoPax ferry fleet is over 25 years old, whereas only $5 \%$ is under 5 years. RoPax ferries operating in Indonesia have a carrying capacity of between $600 \mathrm{GT}$ to $4000 \mathrm{GT}$, depending on the route they serve. For example, for the Merak - Bakaheuni and Ketapang - Gilimanuk routes are served by RoPax ferries with capacity above 2000 GT, while the Bajoe' Kolaka route is served by RoPax ferries with a maximum capacity of 1500 GT. Location arrangement of ship placement and vessel capacity is fully regulated by DGLT, Ministry of Transportation and PT. ASDP Indonesia Ferry. 
Old ships have become one of the obstacles in RoPax ferry operations in Indonesia. This is due to limited space in the car deck and limited operational RoPax ferries. This affects the planning of vehicle parking inside the RoPax ferry. Because of the high number of vehicles and the limited operational RoPax ferries, port authority officers should be able to arrange vehicles by maximizing the existing space on the car deck. The car deck on the RoPax ferry is a place devoted to vehicles that are loaded on the RoPax ferry. In the car deck, all vehicles shall be arranged, so the space in the car deck can be used optimally, and loading and unloading time can be minimized. For vehicle arrangement in the RoPax ferry car deck, port authority and RoPax ferry crews always use the guidelines issued by DGLT, Ministry of Transportations, the Director General of Land Transportation decree no. SK4608 / AP.005 / DRJD / 2012 annex II about Minimum Service Standards for Vehicle Loading. The regulation requires that:

1. Car deck floor should be able to withstand the load of four or more wheel vehicles with maximum axle load of 10 tonnes

2. The highest stack shall not exceed 250 centimetres for vehicle classes I through $\mathrm{V}$ and 420 centimetres for vehicle classes VI through IX

3. The shortest distance between vehicles on the car deck not less than $60 \mathrm{~cm}$ for side end and $30 \mathrm{~cm}$ for both forward and after end.

4. Each ferry is required to provide vehicle props and lashing equipment to maintain longitudinal and transverse stability of ferries

5. Securing lines for vehicles are required for ferries that transit routes with a probability of ship inclination up to 10 degrees due to local sea state.

This regulation is also strengthened by the operational procedures of ship operations (OPS-102) issued by PT. ASDP. OPS-102 was one of the references used by PT. ASDP for drafting the Dangerous Handling Procedures (OPS-109). OPS-102 and OPS-109 set out the duties and responsibilities of each officer of PT. ASDP at the port and before entering the RoPax ferry.

The problem is that neither regulation deals with dangerous goods handling in the RoPax ferry, as set out in IMDG code Chapter 7.5, which deals with the Stowage and Segregation of vehicles carrying dangerous goods cargo on ro-ro ships. In general, the segregation process of dangerous goods cargo follows the flowchart shown in Fig. 6.

Based on survey results, the type of dangerous goods cargo that is mostly transported by ferry transportation in Indonesia is Liquefied Petroleum Gas (LPG), with hazard class 2.1 (flammable gas) and fuel oil (Diesel or Gasoline) with hazard class 3 (Combustible liquid).

According to Fig. 6, all types of cargo normally transported by RoPax ferry should follow the segregation table (Table I) in accordance with general segregation provisions.

Vehicles with dangerous goods cargo should be arranged according to the requirements set out in Table II. However, limited car deck spaces and limited RoPax ferry operations on some shipping routes make the regulation difficult to implement. The high demand for LPG and fuel oil and the limited delivery schedule are also significant obstacles to implementing the regulation.

\subsection{Analysis of emergency/contingency plan}

In November 1997, the IMO assembly adopted resolution A 852 (20) on "Guidelines for a structure of an integrated system of contingency planning for shipboard emergencies". In accordance with the International Safety Management Code (SOLAS Chapter IX, 1994), all ships and the companies responsible for their operations, are required to maintain a Safety Management System. Most countries will have additional national and local regulations which require organizations to develop and maintain an emergency response plan covering their operations. 


\subsection{Analysis of emergency/contingency plan}

In November 1997, the IMO assembly adopted resolution A 852 (20) on "Guidelines for a structure of an integrated system of contingency planning for shipboard emergencies". In accordance with the International Safety Management Code (SOLAS Chapter IX, 1994), all ships and the companies responsible for their operations, are required to maintain a Safety Management System. Most countries will have additional national and local regulations which require organizations to develop and maintain an emergency response plan covering their operations.

Table 1: Survey's result of dangerous goods handling procedure

\begin{tabular}{|c|c|c|c|c|}
\hline no & $\begin{array}{l}\text { Type of } \\
\text { Cargo }\end{array}$ & $\begin{array}{l}\text { Arrive at } \\
\text { Ferry Port }\end{array}$ & $\begin{array}{l}\text { In Parking } \\
\text { Area }\end{array}$ & $\begin{array}{l}\text { Onboard } \\
\text { Ferry }\end{array}$ \\
\hline 1 & Explosive & - & - & - \\
\hline 2 & $\begin{array}{l}\text { Compress } \\
\text { ed gases, } \\
\text { liquefied } \\
\text { Or } \\
\text { dissolved } \\
\text { Under } \\
\text { pressure }\end{array}$ & $\begin{array}{l}\text { Like other } \\
\text { Vehicle (No } \\
\text { segregation) }\end{array}$ & $\begin{array}{l}\text { Parking in } \\
\text { the same } \\
\text { area (No } \\
\text { Segregation) }\end{array}$ & $\begin{array}{l}\text { No } \\
\text { Segregation } \\
\text { onboard } \\
\text { ferry (vehicle } \\
\text { arrangement } \\
\text { based on } \\
\text { ship stability } \\
\text { data) }\end{array}$ \\
\hline 3 & $\begin{array}{l}\text { Flammabl } \\
\text { e liquids }\end{array}$ & $\begin{array}{l}\text { Like other } \\
\text { Vehicle (No } \\
\text { segregation) }\end{array}$ & $\begin{array}{l}\text { Parking in } \\
\text { the same } \\
\text { area (No } \\
\text { Segregation) }\end{array}$ & $\begin{array}{l}\text { No } \\
\text { Segregation } \\
\text { onboard } \\
\text { ferry (vehicle } \\
\text { arrangement } \\
\text { based on } \\
\text { ship stability } \\
\text { data) }\end{array}$ \\
\hline 8 & $\begin{array}{l}\text { Flammabl } \\
\text { e solids }\end{array}$ & $\begin{array}{l}\text { Like other } \\
\text { Vehicle (No } \\
\text { segregation) }\end{array}$ & $\begin{array}{l}\text { Parking in } \\
\text { the same } \\
\text { area (No } \\
\text { Segregation) }\end{array}$ & $\begin{array}{l}\text { No } \\
\text { Segregation } \\
\text { onboard } \\
\text { ferry (vehicle } \\
\text { arrangement } \\
\text { based on } \\
\text { ship stability } \\
\text { data) }\end{array}$ \\
\hline 9 & $\begin{array}{l}\text { Toxic and } \\
\text { infectious } \\
\text { substance } \\
\mathrm{s}\end{array}$ & $\begin{array}{l}\text { Like other } \\
\text { Vehicle (No } \\
\text { segregation) }\end{array}$ & $\begin{array}{l}\text { Parking in } \\
\text { the same } \\
\text { area (No } \\
\text { Segregation) }\end{array}$ & $\begin{array}{l}\text { No } \\
\text { Segregation } \\
\text { onboard } \\
\text { ferry (vehicle } \\
\text { arrangement } \\
\text { based on } \\
\text { ship stability } \\
\text { data) }\end{array}$ \\
\hline 10 & $\begin{array}{l}\text { Radioactiv } \\
\text { e material }\end{array}$ & - & - & - \\
\hline 11 & $\begin{array}{l}\text { Corrosive } \\
\text { substance } \\
\text { s }\end{array}$ & $\begin{array}{l}\text { Like other } \\
\text { Vehicle (No } \\
\text { segregation) }\end{array}$ & $\begin{array}{l}\text { Parking in } \\
\text { the same } \\
\text { area (No } \\
\text { Segregation) }\end{array}$ & $\begin{array}{l}\text { No } \\
\text { Segregation } \\
\text { onboard } \\
\text { ferry (vehicle } \\
\text { arrangement } \\
\text { based on }\end{array}$ \\
\hline
\end{tabular}




\begin{tabular}{|c|c|c|c|c|}
\hline no & $\begin{array}{l}\text { Type of } \\
\text { Cargo }\end{array}$ & $\begin{array}{l}\text { Arrive at } \\
\text { Ferry Port }\end{array}$ & $\begin{array}{l}\text { In Parking } \\
\text { Area }\end{array}$ & $\begin{array}{l}\text { Onboard } \\
\text { Ferry }\end{array}$ \\
\hline 1 & Explosive & - & - & - \\
\hline 2 & $\begin{array}{l}\text { Compress } \\
\text { ed gases, } \\
\text { liquefied } \\
\text { Or } \\
\text { dissolved } \\
\text { Under } \\
\text { pressure }\end{array}$ & $\begin{array}{l}\text { Like other } \\
\text { Vehicle (No } \\
\text { segregation) }\end{array}$ & $\begin{array}{l}\text { Parking in } \\
\text { the same } \\
\text { area (No } \\
\text { Segregation) }\end{array}$ & $\begin{array}{l}\text { No } \\
\text { Segregation } \\
\text { onboard } \\
\text { ferry (vehicle } \\
\text { arrangement } \\
\text { based on } \\
\text { ship stability } \\
\text { data) }\end{array}$ \\
\hline 3 & $\begin{array}{l}\text { Flammabl } \\
\text { e liquids }\end{array}$ & $\begin{array}{l}\text { Like other } \\
\text { Vehicle (No } \\
\text { segregation) }\end{array}$ & $\begin{array}{l}\text { Parking in } \\
\text { the same } \\
\text { area (No } \\
\text { Segregation) }\end{array}$ & $\begin{array}{l}\text { No } \\
\text { Segregation } \\
\text { onboard } \\
\text { ferry (vehicle } \\
\text { arrangement } \\
\text { based on } \\
\text { ship stability } \\
\text { data) }\end{array}$ \\
\hline 8 & $\begin{array}{l}\text { Flammabl } \\
\text { e solids }\end{array}$ & $\begin{array}{l}\text { Like other } \\
\text { Vehicle (No } \\
\text { segregation) }\end{array}$ & $\begin{array}{l}\text { Parking in } \\
\text { the same } \\
\text { area (No } \\
\text { Segregation) }\end{array}$ & $\begin{array}{l}\text { No } \\
\text { Segregation } \\
\text { onboard } \\
\text { ferry (vehicle } \\
\text { arrangement } \\
\text { based on } \\
\text { ship stability } \\
\text { data) }\end{array}$ \\
\hline 9 & $\begin{array}{l}\text { Toxic and } \\
\text { infectious } \\
\text { substance } \\
\text { s }\end{array}$ & $\begin{array}{l}\text { Like other } \\
\text { Vehicle (No } \\
\text { segregation) }\end{array}$ & $\begin{array}{l}\text { Parking in } \\
\text { the same } \\
\text { area (No } \\
\text { Segregation) }\end{array}$ & $\begin{array}{l}\text { No } \\
\text { Segregation } \\
\text { onboard } \\
\text { ferry (vehicle } \\
\text { arrangement } \\
\text { based on } \\
\text { ship stability } \\
\text { data) }\end{array}$ \\
\hline 10 & $\begin{array}{l}\text { Radioactiv } \\
\text { e material }\end{array}$ & - & - & - \\
\hline 11 & $\begin{array}{l}\text { Corrosive } \\
\text { substance } \\
\mathrm{s}\end{array}$ & $\begin{array}{l}\text { Like other } \\
\text { Vehicle (No } \\
\text { segregation) }\end{array}$ & $\begin{array}{l}\text { Parking in } \\
\text { the same } \\
\text { area (No } \\
\text { Segregation) }\end{array}$ & $\begin{array}{l}\text { No } \\
\text { Segregation } \\
\text { onboard } \\
\text { ferry (vehicle } \\
\text { arrangement } \\
\text { based on }\end{array}$ \\
\hline
\end{tabular}




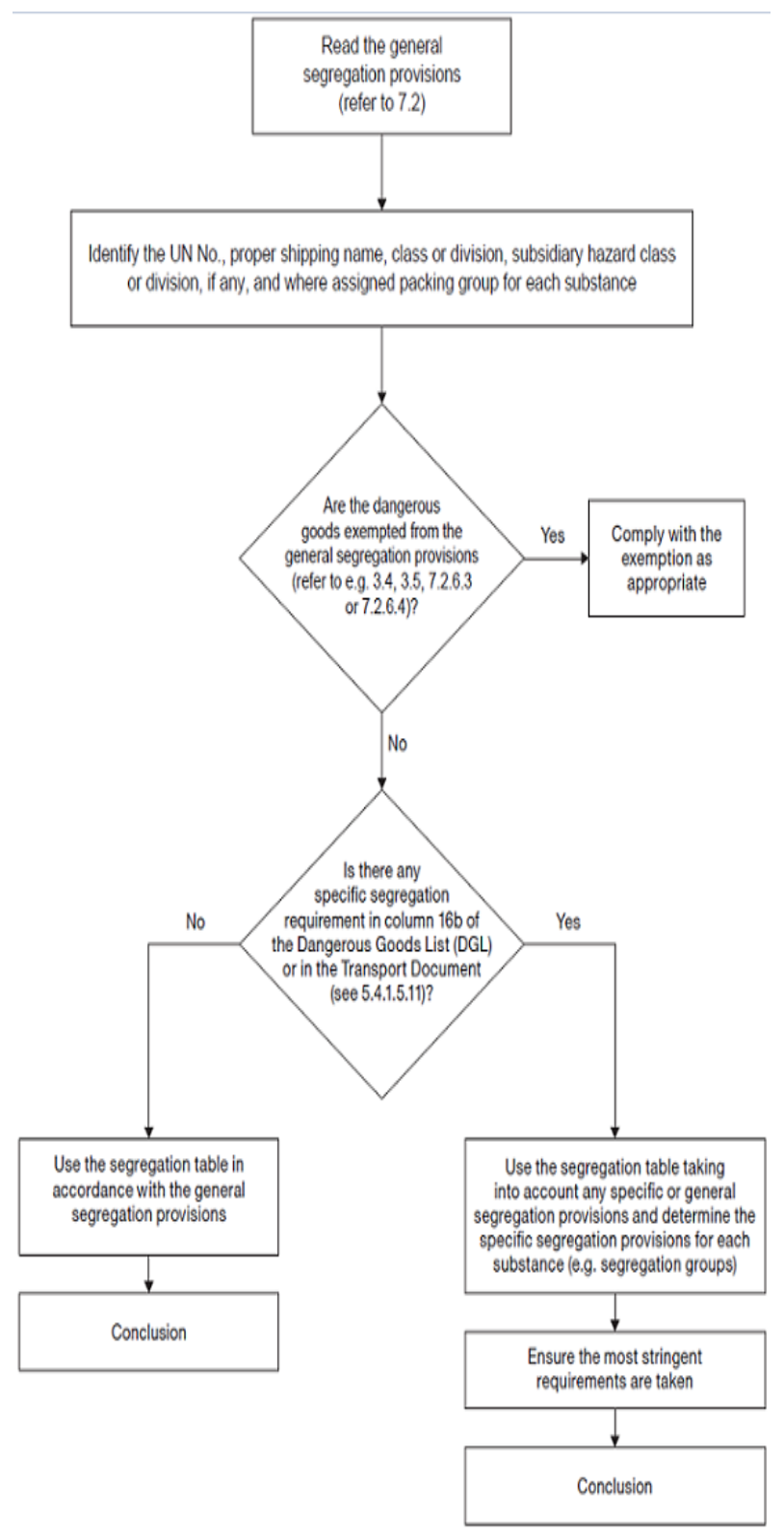

Figure 6: Segregation flow chart

To complement these emergency response requirements, IMDG Code has an additional volume: about guidance on Emergency Response Procedures for Ships Carrying Dangerous Goods. The supplement includes directions for dealing with incidents involving dangerous goods cargo, materials or harmful substances (marine pollution) regulated under the IMDG Code. This guide is intended as support and guidance to all concerned parties in handling dangerous goods to develop emergency procedures and integrate them with the ship contingency plan. 
Table 2: Table of segregation of cargo transport unit on board ro-ro ships

\begin{tabular}{|c|c|c|c|c|c|c|c|}
\hline \multirow{3}{*}{$\begin{array}{l}\text { Segregayion } \\
\text { repquirementit }\end{array}$} & \multicolumn{7}{|c|}{ Hoizontal } \\
\hline & & \multicolumn{2}{|c|}{ Closed versus closed } & \multicolumn{2}{|c|}{ Closed versus open } & \multicolumn{2}{|c|}{ Open versus open } \\
\hline & & Ondeck & Under deck & On deck & Under deck & Ondeck & Under deck \\
\hline "Asuavfrom" & Fore and att & No resticiton & No resticition & Noresticicion & No resticition & Alleast $3 \mathrm{~m}$ & Aflexst $3 \mathrm{~m}$ \\
\hline 1 & Athwertships & No restitition & No restictition & Noresticicion & No resticition & Anllestis $3 m$ & Aflexst3m \\
\hline "Separarted & Fore and aft & At least $6 \mathrm{~m}$ & $\begin{array}{l}\text { At lexat } 6 \text { mor } \\
\text { one bukhead }\end{array}$ & At lesst $6 \mathrm{~m}$ & $\begin{array}{l}\text { Al leasi } 6 \text { m or } \\
\text { ore budkhead }\end{array}$ & Allexst 6 m & $\begin{array}{l}\text { At least } 12 \mathrm{mor} \\
\text { one bulkhead }\end{array}$ \\
\hline 2 & Atwuartships & At least $3 \mathrm{~m}$ & $\begin{array}{l}\text { At least } 3 \text { mor } \\
\text { on bukheadl }\end{array}$ & At least 3m & $\begin{array}{l}\text { Al leasl } 6 \text { mor } \\
\text { ore bulkhead }\end{array}$ & Alleas $6 \mathrm{~m}$ & $\begin{array}{l}\text { At least } 12 \text { mor } \\
\text { one bulkhead }\end{array}$ \\
\hline $\begin{array}{l}\text { "Sepparteded } \\
\text { by a complete }\end{array}$ & Fore and att & At least $12 \mathrm{~m}$ & $\begin{array}{c}\text { At leasi } 24 \mathrm{~m} \\
+ \text { +dedx }\end{array}$ & At least $24 \mathrm{~m}$ & $\begin{array}{l}\text { Afle lesit } 24 \mathrm{~m} \\
\text { +deck }\end{array}$ & Atleast 33m & $\begin{array}{l}\text { Thro decks of } \\
\text { tho bulkeads }\end{array}$ \\
\hline $\begin{array}{c}\text { or hold from" } \\
3\end{array}$ & Atwwartships & At last $12 \mathrm{~m}$ & $\begin{array}{l}\text { Alleasil24m } \\
\text { +dedk }\end{array}$ & Al laxsit24m & $\begin{array}{l}\text { Allessit24m } \\
\text { +desk }\end{array}$ & Prohibitited & Prohibitited \\
\hline $\begin{array}{l}\text { "Separateded } \\
\text { longitucinally" } \\
\text { by an } \\
\text { intervering }\end{array}$ & Fore and aft & Al least $36 \mathrm{~m}$ & 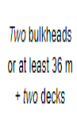 & Al lass $76 \mathrm{~m}$ & 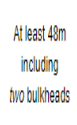 & At least 48m & Pronhibited \\
\hline $\begin{array}{c}\text { cominatinenle } \\
\text { or hold from" } \\
4\end{array}$ & Athwartships & Pronhibited & Prohibitied & Prohibitited & Prohibitiel & Prowibititel & Pronhibited \\
\hline
\end{tabular}

The Guidance is used as a benchmark for all member states to develop codes of practice or guidelines that are in accordance with member state conditions. One example is the regulation issued by the Swedish Transport Agency. Some of its regulations concerning the transport of dangerous goods and safety on board have used the IMDG Code Volume: supplement as a reference in regulatory drafting. Things like this need to be done by regulators and operators in Indonesia. Until now some regulations issued by DGLT and PT. ASDP have not used the IMDG Code Volume: supplement as a reference. One example is the Director General of Land Transportation decree no. SK4608 / AP.005 / DRJD / 2012 annex II about Minimum Service Standards for Vehicle Loading. The regulation is regulated on minimum service standards. However, the regulation does not mention the handling of dangerous goods in ports and on board ships. The same problem is also found in the operational technical guidelines published by PT. ASDP. These technical guidelines do not mention handling of vehicles with dangerous goods cargo.

\section{Conclusions and Recommendations}

\subsection{Conclusions}

The transport of dangerous goods between islands in Indonesia is done by means of domestic ferries, which simultaneously carry passengers between islands. By its nature, transport of dangerous goods by domestic ferry can be considered as one of the most dangerous maritime transport activities. A single accident involving a domestic ferry carrying dangerous goods and passengers at the same time can cause both environmental catastrophe and severe human casualties.

Based on the analysis in chapter five, there are some problems in the transport and handling of dangerous goods cargo using RoPax ferry in Indonesian domestic waterways, such as:

1. Lack of comprehensive regulations governing dangerous goods transport and handling at ferry Ports and on board ferries 
2. Handling procedures for dangerous goods are still local regulations and cannot be implemented properly by all officers in the field

3. Lack of officers at port authorities and RoPax Ferry that have not been certified or trained in dangerous goods handling

4. The quality and professionalism of Human Resources not supported by education and adequate skills, furthermore the distribution of Human Resources in sea transport is unequal, particularly in remote areas, small islands and border countries.

5. Lack of awareness of shippers, forwarding agents and passengers of the importance of following the procedures for transport of dangerous goods

6. Limited facilities owned by ferry ports in Indonesia, especially special parking facilities and temporary storage facilities

7. The number of vehicles is greater than the carrying capacity of ships and cannot be accommodated and served by PT ASDP, causing queues or congestion. Similarly, the parking area around ferry port, particularly during Eid and holidays, cannot sufficiently accommodate vehicles.

\subsection{Recommendation}

In the inland waterways of Indonesia, RoPax ferry safety issues, especially those related to dangerous goods handling, require technical assistance and the special attention of all stakeholders. Furthermore, for a sustainable transport system in Indonesia, the potential of the RoPax ferry as a multi-modal element is immense because RoPax ferry is the only mode of transportation that can transport dangerous goods in large quantities and at an affordable price. Therefore, the safety factor in dangerous goods handling and transport needs to be given more attention. As a result of the conclusions drawn in this paper, the following recommendations as indicated in the following.

1. Upgrading of regulations

2. Construction of suitable RoPax ferry

3. Upgrading maritime education

4. Establishment of domestic waterways transport information system

\section{References}

[1] IMO, “Action Plan adopted to address operational safety of domestic ferries in the Pacific region," 8 November 2012. [Online]. Available: http://www.imo.org/en/MediaCentre/PressBriefings/Pages/48ferrysafety.aspx\#.WC2rU_qLSO0.

[2] ILO, "International Labour Organization," 3011 2004. [Online]. Available: http://www.ilo.org/legacy/english/protection/safework/cis/products/safetytm/transpo.htm.

[3] NTSC, “Investigation Report of Fire on MV. Levina I," Author, Jakarta, 2007.

[4] K. Brunings, "The classification of dangerous goods in containers by sea (handout)," Malmo, 2017.

[5] IMO, "MSC.1/Circ.1216 Revised Recommendations on The Safe Transport of Dangerous Cargoes and Related Activities in Port Areas, ” Author, London, 2007.

[6] BBC, "China explosions: What we know about what happened in Tianjin," China, 2015.

[7] R. Smith, "Shipping Solutions: Hazmat transportations," 10 June 2014. [Online]. Available: www.shippingsolutions.com/blog/hazardous-materials-or-dangerous-goods.

[8] IMO, IMDG code: International Maritime Dangerous Goods Code Volume 1, London: Author, 2014.

[9] United Nations, Recommendations on the Transport of Dangerous Goods Volume 1, Geneva: Author, 2013.

[10] United Nations, European agreement concerning the International Carriage Dangerous Goods by Inland Waterways (ADN), Geneva: Author, 2001.

[11] T. H. Allegri, Handling and Management of Hazardous Materials and Waste, New York: Chapman and Hall, 1986.

[12] IMO, IMDG Code Supplement, 2014 Edition, London: Author, 2014.

[13] MoT, "Rencana pembangunan jangka panjang 2005-2025 (Long term Development Planning, 2005-2025)," Author, Jakarta, 2008. 
[14] MoT, "Rencana Induk Pelabuhan Nasional (National port master plan)," Author, Jakarta, 2016.

[15] DGLT, "Master plan perhubungan darat (land transport master plan)," Author, Jakarta, 2005.

[16] DGLT, "Perhubungan darat dalam angka (Land transport in number)," Author, Jakarta, 2014.

[17] DGLT, "Standar pelayanan minimum angkutan penyeberangan (minimum ferry service standard)," Author, Jakarta, 2003.

[18] DGLT, "Pengoperasian Pelabuhan Penyeberangan (Ferry Port Operation), " Author, Jakarta, 2006.

[19] A. Mullai, "Maritime Transport and Risks of Packaged Dangerous Goods, " Dagob Publications, Turku, 2006.

[20] MoT, "KM No. 17/2000: Pedoman Penanganan Bahan/Barang Berbahaya Dalam Kegiatan Pelayaran di Indonesia (Guidelines for Handling of Dangerous Goods / Materials in Shipping Activities in Indonesia), "Author, Jakarta, 2000.

[21] IMO, "A.852(20) Guidelines for a structure of an integrated system of contingency planning for shipboard emergencies," IMO, London, 2013.

[22] IMO, "Illustrations of Segregation of Cargo Transport Units on Board Containerships and Ro-Ro Ships," Author, London, 2012 